\title{
THE PINEAPPLE DISEASE OF SUGAR CANE IN PUERTO RICO
}

\author{
By Melville T. Cook, Plant Pathologist, \\ Insular Experiment Station, Río Piedras, P. R.
}

This disease is caused by Thielaviopsis paradoxa (De Seynes) von Höhn and is widely distributed throughout the cane-growing parts of the world. This fungus was found first on pineapple in 1886 by De Seynes, who described it under the name of Sporochisma paradoxum. In 1892 Saccardo referred it to Chalara paradoxa (De Seynes) Sace. In 1893 Went reported Thielaviopsis ethaceticus as the cause of a serious disease of sugar cane in Java. In 1904 von Höhnel reported that the organisms described by De Seynes and by Went were the same and made the combination Thielaviopsis paradoxa which has been very generally accepted from that time to the present. Dade (1928) (4) reported the finding of a Ceratostomella which he believed to be the perfect stage of the fungus which would become Ceratostomella paradoxa.

The fungus has been reported as attacking a large number of species of plants-sugar cane, pineapple, plantain, mango, coconut, date palm and many others. It has been reported from nearly all the countries in which sugar cane is grown. The geographical distribution according to the International Survey of the Disease of Sugar Cane (3) with a few additions, is as follows: Argentina, Australia, British Guiana, Ceylon, Colombia, Cuba, Dutch East Indies, Fiji, Formosa, Gold Coast, Hawaii, India, Jamaica, Java, Lesser Antilles, Madeira, Mauritius, Malaya, Mexico, Philippines, Portuguese East Africa, Puerto Rico, Reunion, Santo Domingo and Southern United States. It is reasonable to suppose that it occurs in all the other sugar-cane-growing countries. In Puerto Rico this fungus attacks the pineapples and is sometimes the cause of heavy losses in fruits and in young slips which have been planted for a short time. It attacks the coconuts and is sometimes the cause of the falling of a large number of young fruits and sometimes attacks the buds, causing a deformity of the young leaves and a slow dying of the trees. It attacks sugar cane, causes a rotting of seed cuttings and poor germinations, which will be described in this paper.

Went (1893) in the first record of this fungus attacking sugar. cane stated that it was the cause of a serious disease. Some of the 
records since that time have indicated that it was serious while others have indicated that it was of little or no importance. Johnston (7) conducted experiments in Puerto Rico which were published in 1913 for the purpose of determining the relative resistance of a number of varieties. In these experiments he punched a hole in the end of the seed eutting and injected the fungus with a $10 \mathrm{cc}$ syringe. He reports injuries ranging from 15 to 90 per cent but none of the varieties used by him are of commercial importance on the island at this time. He also conducted experiments for the control of the disease and reported that best results were obtained by treating seed cuttings with 4-5-50 Bordeaux and by sealing the cut ends with tar.

When the writer came to Puerto Rico in 1923 , inquiries were made concerning the problems of germination. All reports indicated that poor germination was rare and that when it did occur that it was due to poor seed cuttings. Other problems required the time of the writer and no further consideration was given to the problem of poor germination until the spring of 1930 when oux attention was called to very poor germination in one locality. A personal examination showed that the soil was heavy and poorly drained and that the seed cuttings were rotting as a result of attacks of Thielaviopsis paradoxa. Experiments were started on a small plot of ground at the Experiment Station and have been conducted over a period of three years.

The method consisted in the planting of fifty seed cuttings each of some of our most important varieties, using pieces with three eyes and allowing them to grow for six to twelve weeks. At the end of the time, they were lifted and the germinating eyes counted. In order to make sure of uniform inoculations, the fungus was grown in large flasks and put into a bucket of water. The eanes were dipped in this mixture just before planting. After a time, the soil was so thoroughly infested that this was unnecessary. This was demonstrated by treating one half of the euttings in one planting. When the young plants were lifted and the germinating eyes counted, the results were practically the same for the treated and untreated cuttings. Fleven crops were grown. The soil became so heavily infested as a result of repeated use for this work that the germination of the last three crops was very low. The varieties used were B.H.-10(12), S.C.-12(4), Uba, P.R.-801, 803, 807, 809, 820, 826, Co.-281, F.C.-916, P.O.J.-2714, 2725, 2727 and 2878 . The work has not been altogether satisfactory because it was impossible to control the environmental factors in field experiments. One planting was damaged by the overflow of the river and the data very unreliable. However, the results are of some value. These results may be summarized as follows: 
1. The so-called pineapple disease of sugar cane in Puerto Rico which is caused by a fungus (Thielaviopsis paradoxa) is occasionally very severe.

2. It is most severe on heavy, clay, poorly drained soils.

3. It is most severe during the cooler months of the year.

4. During the summer months the fungus appears to be more abundant or more active in the higher elevations (up to $2000 \mathrm{ft}$.) than in the coastal plains.

5. In heavily infected soil the rotting of seed cuttings may be as great during dry as during rainy weather, if other conditions are favorable.

6. With two exceptions, the germination tests were below 50 per cent. Both exceptions were with Co.-281. The average germination in Puerto Rico is about 70 or 75 per cent according to experienced cane growers who have been consulted by the writer.

7. Co.-281 proved to be most resistant with other varieties in the following order: P.O.J.-2878, P.R.-801, P.R.-803, P.R.-826, Uba, B. H.-10(12), P.R.-820, P.R.-807, F.C.-916, P.0.J.-2725, S.C.-12(4), P.O.J.-2714, P..R.-809, P.O.J.-2727.

\section{SrMProms}

The fungus has been recognized as a wound parasite for many years. It penetrates the cut ends of the seed pieces and destroys the cell walls of the parenchyma tissues. The first evidence of an attack by this fungus is a reddish discoloration of the tissues, followed by a black color and by decay. The decay is accompanied by an odor which is very similar to that of pineapples which are rotted by this fungus. When the decay is well advanced, if one will cut through the rind and break a cane the fibro-vascular bundles can be pulled out in mass like the hairs of a brush.

$N_{0}$ studies were made on the temperature relations but Klotz and Fawcett (8) state that the optimum temperature for this fungus on the date palm is 24 to $271 / 2$ degrees $C$. This is approximately 64.5 to 67.5 degrees $F$. which is a little lower than the temperature of our coastal plains during the winter months.

\section{TREATMENTS}

Severe outbreaks of this disease in Puerto Rico are so rare that it is not necessary to use a treatment very often. However, severe outbreaks are likely to occur at any time on poorly drained soils, es- 
pecially during the winter months. These outbreaks are expensive in proportion as they make replanting necessary. The first and most. important treatment is a well-drained soil. In case of heavily infected soil it may be desirable to plant some other erop for a season or to use the Bordeaux treatment. This must be decided by the grower on basis of farm management and economics. In case the Bordeaux treatment is used, the cane should be treated very soon after cutting. If the seed cuttings become infected before treatment, the treatment is useless. When the grower has a few cuttings of a new variety, it is advisable to protect them by dipping the cut ends in tar or melted paraffin.

\section{The Three-Bud Seed Piece}

The Puerto Rican practice is to use three-bud seed cuttings. This practice is no doubt the result of long years of experience and the writer believes that the T. paradoxa has been the deciding factor in favor of this method. Experimental work by the writer and others has demonstrated that there is a higher germination with three-bud cuttings than with cuttings of two buds or one bud. This is probably due to the length of the seed pieces rather than to the number of buds. In a long seed cutting the fungus has to travel a much longer distance than in short seed pieces and the buds have a better chance to germinate and become established before the fungus reaches them. The writer has found that when short seed cuttings for experimental studies are planted in unsterilized soil, it is advisable to dip the cut ends in melted paraffin or tar.

\section{Other Causes of Poor Germination}

Marasmius sacchari is one of the minor causes of poor germination in Puerto Rico. In one planting of one variety, this fungus killed 20 per cent of the buds.

Other causes of poor germination that have been reported from other countries are Colletotrichum falcatum and Melanconium sacchari in Louisiana, Ceratostomella adiposum in India and Lasiodiplodia theobromae in the Philippine Islands.

\section{BIBLIOGRAPHY}

1. Butler, E. J. Fungus disease of sugar cane in Bengal. India Dept. Agr. Mem., Bot. Ser. 1(3) : 1-53. (1906).

2. Cook, Melville T. Coconut Fall. Journ. of the Dept. of Agri. of Puerto Rico. Vol. 8, No. 4, 3 pages. (1924.) 
3. Rotting of Seed Cuttings in Porto Rico. Proc. of the Fourth Congress Int. Soc. Sugar Cane Tech. Bull. 36. (1932.)

4. Dade, H. A. Ceratostomello paradoxa, the Perfect Stage of Thielaviopsis paradoxa (De Seynes). Brit. Mycol. Soc. Trans. 13: 189-192. (1928.)

5. Edgerton, C. W. Some Sugar-Cane Diseases. La. Agri. Exp. Sta. Bull. 120. (1910.)

6. Fawcett, G. L. Black Rot of Sugar Cane. Rev. Ind. Agri. Tucuman. 21:55-59. (1931.)

7. Johnston, J. R. Selection and Treatment of Cane Seed. Experiment Station of the Sugar Producers' Association of Puerto Rico. Bulletin No: 6 pp. 1-29. (1913.)

8. Klotz, L. J. and H. S. Fawcett. Black Scorch of the Date Palm caused by Thielaviopsis. Jour. Agri. Research. 44:155-166. (1932.) 